\title{
A Review of Quality Measures for Assessing the Impact of Antimicrobial Stewardship Programs in Hospitals
}

\author{
Mary Richard Akpan ${ }^{1,+}$, Raheelah Ahmad ${ }^{2,+}$, Nada Atef Shebl ${ }^{1,+}$ and \\ Diane Ashiru-Oredope ${ }^{3, *,+}$
}

Received: 28 September 2015; Accepted: 4 January 2016; Published: 13 January 2016

Academic Editors: Christopher C. Butler and Jerod Nagel

1 Department of Pharmacy, Pharmacology and Postgraduate Medicine, University of Hertfordshire, Hatfield, AL10 9AB, UK; m.akpan@herts.ac.uk (M.R.A.); n.a.shebl@herts.ac.uk (N.A.S.)

2 NIHR Health Protection Research Unit in Healthcare Associated Infection and Antimicrobial Resistance at Imperial College London, Hammersmith Campus, Du Cane Road, London, W12 0NN, UK; raheelah.ahmad00@imperial.ac.uk

3 Antimicrobial Resistance Program, Public Health England, London, NW9 5EQ, UK

* Correspondence: diane.ashiru-oredope@phe.gov.uk; Tel.: +44-20-8327-6689

+ These authors contributed equally to this work.

\begin{abstract}
The growing problem of antimicrobial resistance (AMR) has led to calls for antimicrobial stewardship programs (ASP) to control antibiotic use in healthcare settings. Key strategies include prospective audit with feedback and intervention, and formulary restriction and preauthorization. Education, guidelines, clinical pathways, de-escalation, and intravenous to oral conversion are also part of some programs. Impact and quality of ASP can be assessed using process or outcome measures. Outcome measures are categorized as microbiological, patient or financial outcomes. The objective of this review was to provide an overview of quality measures for assessing ASP and the reported impact of ASP in peer-reviewed studies, focusing particularly on patient outcomes. A literature search of papers published in English between 1990 and June 2015 was conducted in five databases using a combination of search terms. Primary studies of any design were included. A total of 63 studies were included in this review. Four studies defined quality metrics for evaluating ASP. Twenty-one studies assessed the impact of ASP on antimicrobial utilization and cost, 25 studies evaluated impact on resistance patterns and/or rate of Clostridium difficile infection (CDI). Thirteen studies assessed impact on patient outcomes including mortality, length of stay (LOS) and readmission rates. Six of these 13 studies reported non-significant difference in mortality between pre- and post-ASP intervention, and five reported reductions in mortality rate. On LOS, six studies reported shorter LOS post intervention; a significant reduction was reported in one of these studies. Of note, this latter study reported significantly $(p<0.001)$ higher unplanned readmissions related to infections post-ASP. Patient outcomes need to be a key component of ASP evaluation. The choice of metrics is influenced by data and resource availability. Controlling for confounders must be considered in the design of evaluation studies to adequately capture the impact of ASP and it is important for unintended consequences to be considered. This review provides a starting point toward compiling standard outcome metrics for assessing ASP.
\end{abstract}

Keywords: antimicrobial stewardship; antimicrobial resistance; quality indicators; outcome; patient; infectious diseases 


\section{Introduction}

Antimicrobial resistance (AMR) is a growing public health threat which has attracted the attention of national and international bodies. A recent World Health Organization (WHO) surveillance of resistance to antibacterial drugs in bacteria commonly associated with hospital and community infections revealed increasing resistance and/or decreased susceptibilities in the studied bacteria [1]. Resistance of Escherichia coli to third-generation cephalosporins and fluoroquinolones and Staphylococcocus aureus to methicillin (Methicillin Resistant Staphylococcous aureus, MRSA) are reported to be $50 \%$ or more in five out of the six WHO regions [1]. Klebsiella pneumoniae resistance to third-generation cephalosporins is reported to be greater than $50 \%$ in all six WHO regions. Carbapenem-resistant K. pneumoniae is reportedin all WHO regions, with reports in two regions exceeding $50 \%$. Also, non-susceptibility of Streptococcus pneumoniae to penicillin is reported to be more than $50 \%$ in all six WHO regions. A related English AMR surveillance report revealed increased resistance of E. coli and K. pneumoniae to ciprofloxacin, third-generation cephalosporins, gentamicin, and imipenem/meropenem [2]. The report however indicated decreased resistance of Pseudomonas aeruginosa to ceftazidime, gentamicin, and imipenem/meropenem [2]. Recent reports highlightthat patients with infection caused by drug resistant bacteria have a two-fold increase in mortality compared to those with infection with sensitive bacteria [1,3].

Available estimates indicate that between $25 \%-50 \%$ of hospitalized patients receive antibiotics, with between $30 \%$ and $50 \%$ of antibiotic use being inappropriate [4,5]. Published literature demonstrates a strong link between antibiotic use and the development of resistance [3,6-8]. Antimicrobial stewardship programs are therefore quality motivated interventions aimed at improving the use of antibiotics in healthcare facilities. The primary goal is to optimize clinical outcomes and minimize unintended consequences such as Clostridium difficile infection (CDI) and resistance [4,9]. Strategies to achieve these goals have included prospective audit with intervention and feedback, and formulary restriction and preauthorization. Supplemental strategies include education, guidelines and clinical pathways, antimicrobial cycling and scheduled antimicrobial switch, antimicrobial order forms, automatic stop orders, combination therapy, streamlining or de-escalation of therapy, dose optimization, conversion from parenteral to oral therapy, and computer surveillance and decision support $[4,10]$.

A Cochrane review of interventions to improve antibiotic prescribing for hospital inpatients classified these strategies into three main groups namely:

i persuasive interventions: these include education, audit and feedback, guidelines and clinical pathways.

ii restrictive interventions: formulary restriction, prior approval or preauthorization from infectious diseases (ID) physician, microbiologist or pharmacists, automatic stop orders, antimicrobial cycling or scheduled switch, antibiotic order forms.

iii structural interventions: computerized records, computerized decision support, example computer physician order entry (CPOE) [11].

Effective antimicrobial stewardship programs require a multidisciplinary team with responsibility for promoting prudent antimicrobial use. The Infectious Diseases Society of America and the Society for Healthcare Epidemiology of America (IDSA/SHEA) ASP guidelines [4] recommend a multidisciplinary team which includes an ID physician and a clinical pharmacist with infectious diseases training as core members. Inclusion of a clinical microbiologist, information system specialist, infection control specialist, hospital epidemiologist, and hospital administrator is considered optimal. The English antimicrobial stewardship (AMS) toolkit: "Start Smart, then Focus" recommends other core members should be present, an acute care physician, a surgeon, a senior member of the pharmacy management team, an anesthetist, a pediatrician, and a senior nurse [12].

There is an increased call on healthcare organizations to develop quality measures or indicators to monitor and evaluate the impact of ASP [4,12-14]. Previous reviews have reported on the impact of 
ASP in reducing antimicrobial cost, AMR, superinfection, and patient outcomes (such as length of stay (LOS), readmission rate, and mortality) $[11,15]$. The objective of this review was to provide an overview of reported quality measures for assessing ASP and report on the impact of published antimicrobial stewardship studies on these measures, with particular focus on patient outcome measures.

\section{Methods}

A literature search of papers published in English between the 1990 and June 2015 was identified through a search of five databases: Scopus, Medline, CINAHL, Pubmed, and Embase using the following search terms: ("antimicrobial stewardship" OR "antimicrobial stewardship program" OR "antibiotic control program" OR "antibiotic policy" OR "antibiotic management program"); (outcomes OR impact OR "quality measure" OR "performance measures" OR "length of stay" OR "clinical improvement" OR "C. difficile infection" OR mortality OR resistance OR readmission OR MRSA).

\section{Study Inclusion and Exclusion Criteria}

Only primary research studies, published in English and which met the following criteria were included:

- Defined and/or developed quality measures for assessing ASP in hospital settings.

- Used quality performance measures (such as change in antimicrobial use) and outcome measures (including resistance patterns, rates of CDI, LOS, readmission, mortality, and cost savings) in evaluating impact of ASP.

- Involved adult inpatients in acute and community hospital settings.

Studies excluded were:

- Those that reported prevalence of ASP without evaluation of impact.

- ASP studies in pediatrics and long term care facilities.

\section{Results}

The initial search returned 4319 articles. Of these, 152 met the inclusion criteria, and a full-text evaluation was carried out on 63 studies. In summary, four studies defined quality metrics for evaluating ASP. Twenty-one studies assessed impact on antimicrobial utilization and cost, 25 studies evaluated impact on resistance patterns and/or rate of CDI. Thirteen studies assessed impact on patient outcomes including mortality, LOS, and readmission rates.

\subsection{Studies that Defined Quality Measures for Evaluating ASP}

Table 1 includes studies [16-19] that developed or defined quality measures for evaluating ASP. Methods used were modified Delphi technique, survey, and interviews. Bumpass et al. [19] surveyed ID physicians' and pharmacists' opinions of AMS metrics considered important in evaluating ASP. The authors reported that although appropriateness of antimicrobial use, infection-related mortality, and antibiotic associated length of stay were considered more important outcomes by those surveyed, antimicrobial use and cost were the most commonly collected metrics. 
Table 1. Studies that defined quality measures for evaluating antimicrobial stewardship programs antimicrobial stewardship programs (ASP).

\begin{tabular}{|c|c|c|c|c|}
\hline Study & Method Used & Category of Measure & & Quality Measures Identified \\
\hline $\begin{array}{l}\text { Nathwani et al., } \\
2002[16]\end{array}$ & Expert panel & $\begin{array}{l}\text { Process measures for } \\
\text { glycopeptideprescribing }\end{array}$ & $\begin{array}{l}\text { i } \\
\text { ii } \\
\text { iii } \\
\text { iv }\end{array}$ & $\begin{array}{l}\text { total number of glycopeptide in defined } \\
\text { daily dose (DDD)/1000-patient days } \\
\text { number of alert antibiotic forms } \\
\text { completed for glycopeptide } \\
\text { number of patients prescribed } \\
\text { glycopeptide appropriately according } \\
\text { to policy } \\
\text { number of patients prescribed } \\
\text { glycopeptide inappropriately }\end{array}$ \\
\hline $\begin{array}{l}\text { Chen et al., } \\
2011 \text { [17] }\end{array}$ & $\begin{array}{l}\text { Survey by questionnaireand } \\
\text { interviews }\end{array}$ & Process and outcome & $\begin{array}{l}\text { i } \\
\text { ii } \\
\text { iii } \\
\text { iv }\end{array}$ & $\begin{array}{l}\text { DDD/1000 patient-days against state or } \\
\text { national data } \\
\text { quantity of antimicrobial use } \\
\text { within hospital } \\
\text { number of prescriptions of restricted } \\
\text { antibiotic complaints with } \\
\text { approved guideline. } \\
\text { cost savings }\end{array}$ \\
\hline $\begin{array}{l}\text { Morris et al., } \\
2012[18]\end{array}$ & Modified Delphi & Process and outcome & $\begin{array}{r}\text { i } \\
\text { ii } \\
\text { iii } \\
\text { iv }\end{array}$ & $\begin{array}{l}\text { days of therapy } / 1000 \text { patient-days } \\
\text { number of patients with specific } \\
\text { organisms that are drug resistant } \\
\text { mortality related to } \\
\text { antimicrobial-resistant organisms } \\
\text { conservable days of therapy among } \\
\text { patients with community-acquired } \\
\text { pneumonia (CAP), skin and soft-tissue } \\
\text { infections (SSTI), or sepsis and } \\
\text { bloodstream infections (BSI) } \\
\text { unplanned hospital readmission within } \\
30 \text { days after discharge from the } \\
\text { hospital in which the most responsible } \\
\text { diagnosis was one of CAP, SSTI, sepsis } \\
\text { or BSI }\end{array}$ \\
\hline $\begin{array}{l}\text { Bumpass et al., } \\
2014[19]\end{array}$ & Survey & Process and outcome & $\begin{array}{r}\text { i } \\
\text { ii } \\
\text { iii } \\
\text { iv } \\
\text { V }\end{array}$ & $\begin{array}{l}\text { appropriateness of antimicrobial use } \\
\text { infection-related mortality rate } \\
\text { antibiotic-associated length of stay } \\
\text { antimicrobial use } \\
\text { antimicrobial cost }\end{array}$ \\
\hline
\end{tabular}

\subsection{Impact of ASP on Quality Measures}

Impact of ASP on different quality measures is summarized in Tables $2-4$. This is grouped into:

- impact on antimicrobial use and cost savings

- impact on C. difficile infection and resistance patterns

- impact on patient outcomes (LOS, readmission rate, mortality)

Some of the studies used more than one measure in assessing impact and majority (29) employed before-after or pre-post-intervention (quasi-experimental) design without control. The pre-phase consisted of retrospective collection of baseline data before ASP implementation.

\subsubsection{Impact of ASP on Antimicrobial Use and Cost of Antimicrobials}

Change in the use of specific antibiotic or antibiotic class is considered a process measure $[4,20]$. The majority of the programs that assessed impact of ASP on antibiotic use also assessed cost savings. Twenty-one studies assessed impact on antimicrobial use and/or cost. The majority of 
the studies that reported significant cost savings did not provide the cost of implementing the program. Table 2 summarizes studies [21-41] that assessed the impact of ASP on antimicrobial use and cost of antimicrobials.

Table 2. Impact of ASP on antimicrobial use and cost of antimicrobials.

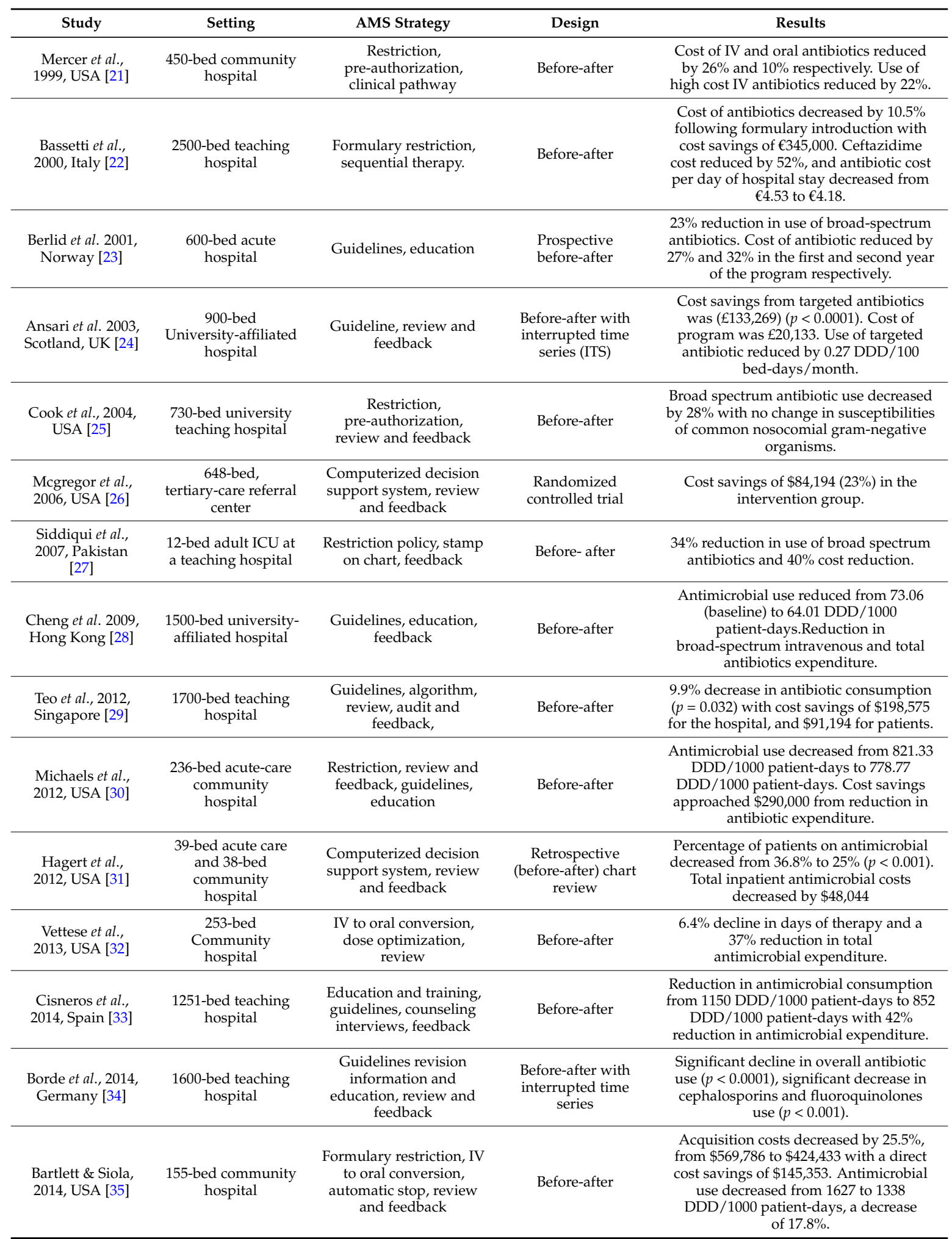


Table 2. Cont.

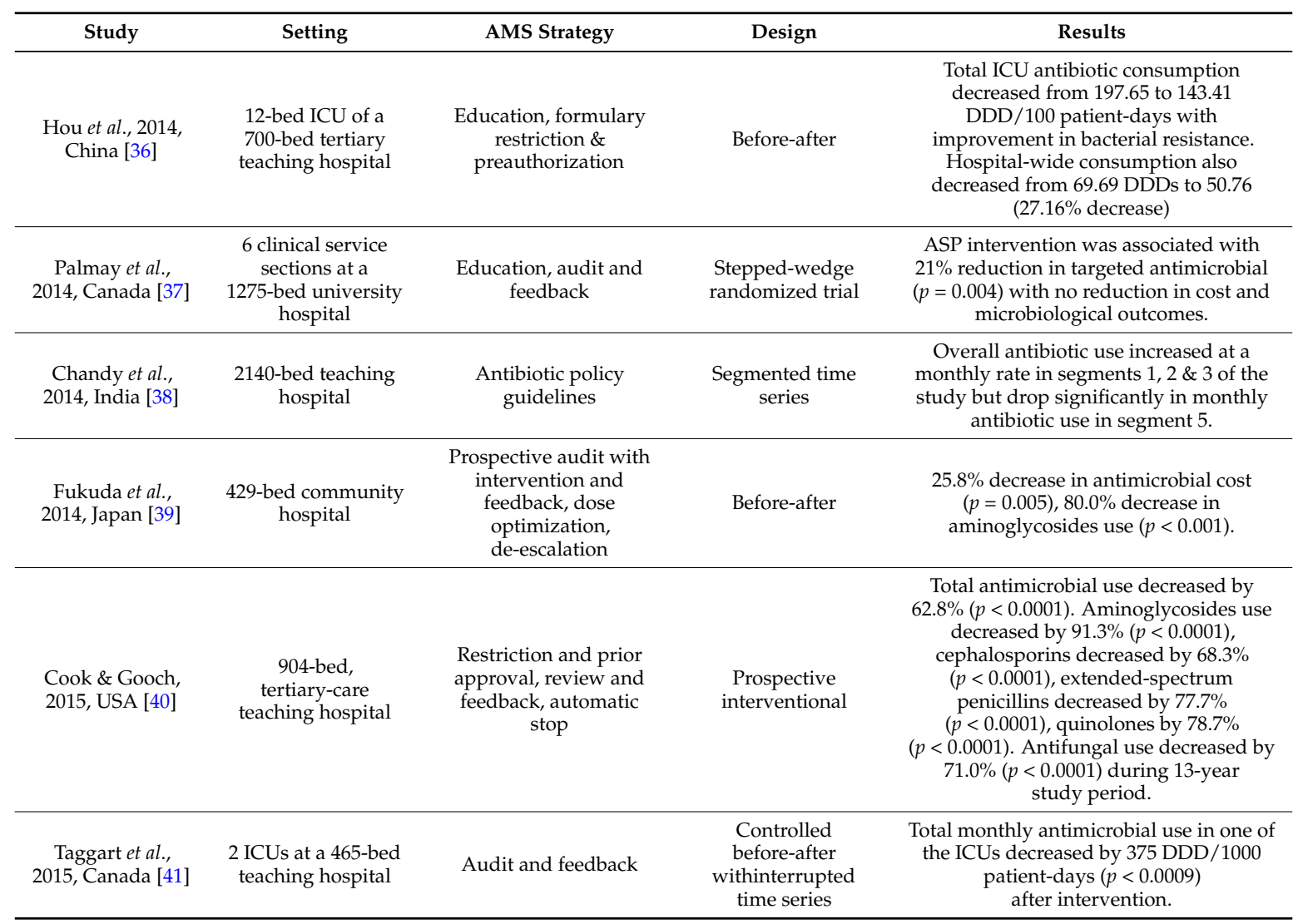

\subsubsection{Impact of ASP on Resistance Patterns and Clostridium Difficile Infection (CDI)}

A total of 25 studies [42-66] assessed the impact of ASP on microbiological outcomes (bacterial resistance patterns) and/or CDI rates. Thirteen of the 25 studies assessed impact on CDI rates and other outcomes. Nine out of 13 studies reported a statistically significant reduction in the rate of CDI following ASP implementation [41,42,51,52,54,56,58,61,64]. Khan and Cheesbrough [44] and Malani et al. [62] reported a progressive fall in the rate of $C$. difficile-associated diarrhea (CDAD) and $50 \%$ decrease in the likelihood of developing CDI respectively. A restriction policy on ciprofloxacin and ceftriaxone resulted in a $70.20 \%$ reduction in the CDI with non-significant effect on extended spectrum beta lactamases (ESBL) — producing colliforms $(p=0.075)$ [63]—a proxy for antimicrobial resistance development.

Twelve studies assessed the impact on the resistance patterns of organisms commonly associated with hospital infections (ESKAPE: Enterococcus faecium, Staphylococcocus aureus, Klebsiella pneumoniae, Acinetobacter baumannii, Pseudomonas aeruginosa, and Enterobacter species, e.g., Escherichia coli) [67] and reported a reduction in resistance or unchanged susceptibilities in these organisms following AMS interventions. Saizy-Callaert et al. [45] reported a significant fall in the rate of ESBL-producing Enterobacteriaceae $(p<0.001)$ following the development of a multidisciplinary consultative approach which included developing local prescribing consensus with all prescribers; restricted prescriptions policy; regular audits of use of restricted antibiotics and institutional wide training and information for prescribers. A restriction policy on ceftazidime resulted in a significant decrease in A. baumannii ( $p=0.01)$ [48]. Table 3 summarizes studies that assessed impact on CDI rate and resistance patterns. 
Table 3. Impact of ASP on resistance patterns and C. difficile infection.

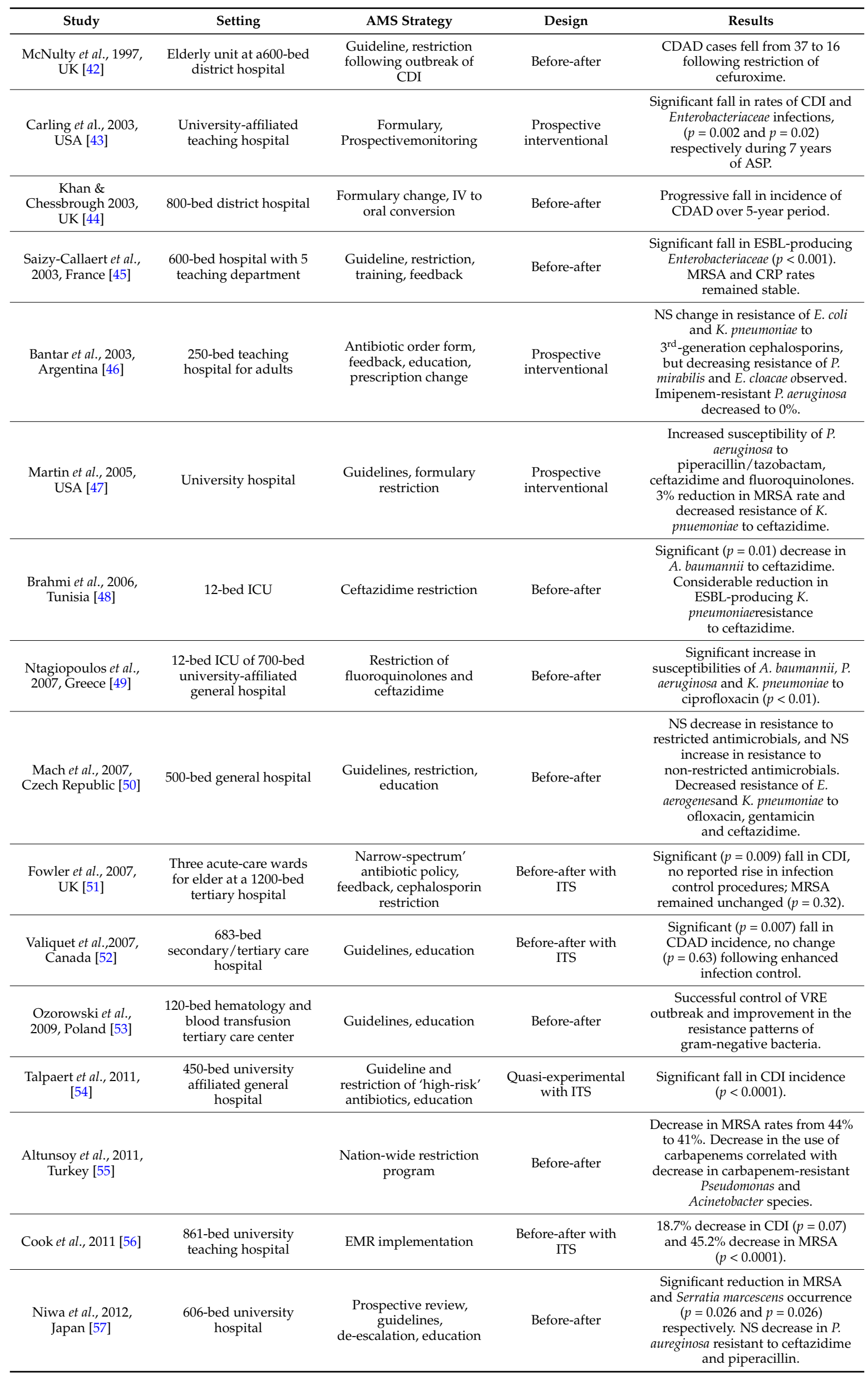


Table 3. Cont.

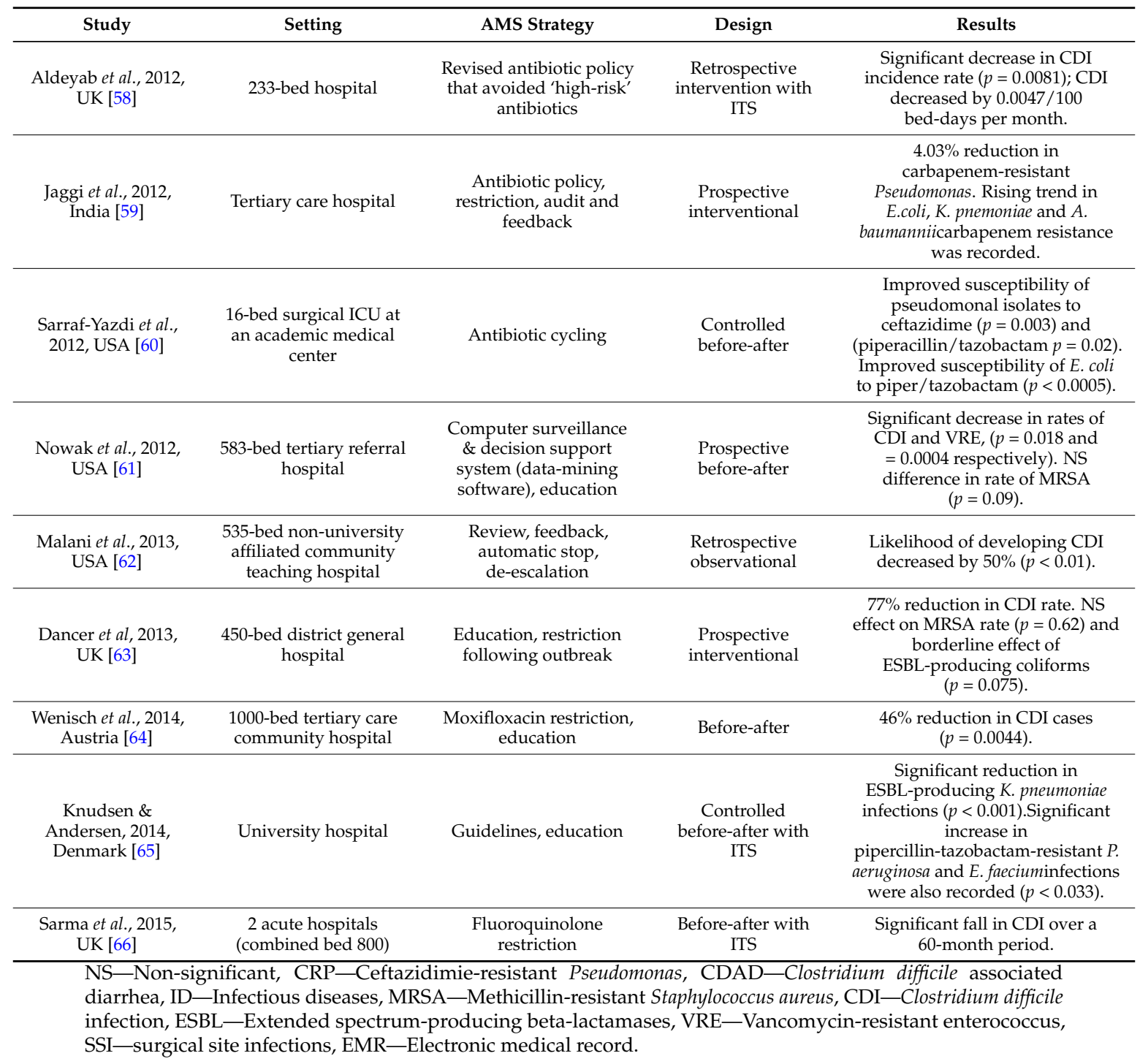

\subsubsection{Impact of ASP on Patient Outcomes}

Thirteen studies [68-80] were identified that reported impact on patient outcomes. Gums et al. [68] reported shorter LOS in the intervention group than the control group $(9.0 v s .5 .7 ; p=0.0001)$ and $6.3 \%$ mortality in the intervention group compare to $12.0 \%$ in the control group. Similarly, $\mathrm{Ng}$ et al. [70] reported a significant $(7.46$ and 6.97 respectively; $p<0.001$ ) difference in LOS between the periods before and after ASP implementation with no difference in mortality. Six studies reported non-significant difference in mortality $[69,71-73,75,78]$.Okumura et al. [80] however reported lower 30-day mortality with bundled ASP (intervention consisting of clinical pharmacist chart review, discussion with microbiologist and infectious disease physicians, local education and continuous follow-up) $(p<0.01)$ than conventional ASP. One study assessed incidence of adverse reactions following carbapenem de-escalation and reported that the de-escalated group had fewer adverse reaction $(11 / 204(5.4 \%) v s$. $12 / 96(12.5 \%) ; p=0.037)$ [79].

A summary of studies that assessed impact on patient outcomes is provided in Table 4 . 
Table 4. Impact of ASP on patient outcomes.

\begin{tabular}{|c|c|c|c|c|}
\hline Study & Setting & AMS Strategy & Design & Results \\
\hline $\begin{array}{l}\text { Chang et al., 2006, } \\
\text { Taiwan [69] }\end{array}$ & 921-bed medical center & $\begin{array}{l}\text { Guidelines, restriction } \\
\text { and prior approval, } \\
\text { education }\end{array}$ & Before-after & $\begin{array}{l}\text { No change in LOS, mortality and } \\
\text { readmission rates in the pre- and } \\
\text { post-intervention periods. }\end{array}$ \\
\hline $\begin{array}{l}\text { Ng et al., 2008, } \\
\text { Hong Kong [70] }\end{array}$ & 1800-bed acute hospital & $\begin{array}{l}\text { Guideline, antibiotic } \\
\text { order form, restriction, } \\
\text { review and feedback }\end{array}$ & Before-after & $\begin{array}{c}\text { Significant difference in LOS } \\
\text { between pre- and post-ASP }(7.46 \\
\text { vs.6.97 days, }(p<0.001) \text {. } \\
\text { NS difference in mortality }(8.8 \% \\
v s .8 .4 \%,(p=0.28) \text {. Significant } \\
\text { unplanned readmissions related } \\
\text { to infections post-ASP }(17.6 \% \text { vs. } \\
18.7 \%,(p=0.008) .\end{array}$ \\
\hline $\begin{array}{l}\text { Liew et al., 2012, } \\
\text { Singapore [72] }\end{array}$ & $\begin{array}{c}\text { 1559-bed tertiary-care } \\
\text { hospital }\end{array}$ & $\begin{array}{l}\text { Guidelines, posters, } \\
\text { prospective review with } \\
\text { intervention }\end{array}$ & $\begin{array}{l}\text { Retrospective } \\
\text { review of ASP } \\
\text { interventions }\end{array}$ & $\begin{array}{l}\text { Shorter LOS in patients whose } \\
\text { physicians accepted interventions } \\
\text { than those interventions were } \\
\text { rejected (19.9 vs. } 24.2 \text { days, } \\
p<0.001) \text {. NS }(p=0.191) \\
\text { difference in overall mortality and } \\
\text { infection-related mortality } \\
\text { between the two groups. } \\
\text { Infection-related readmission and } \\
\text { 14-day re-infection was higher in } \\
\text { patients whose physicians } \\
\text { rejected AS interventions } \\
(p<0.001 \text { and } p=0.009) \\
\text { respectively. }\end{array}$ \\
\hline $\begin{array}{l}\text { Rimawi et al., 2013, } \\
\text { USA [74] }\end{array}$ & $\begin{array}{c}\text { 24-bed medial ICU at } \\
\text { 861-bed teaching } \\
\text { hospital }\end{array}$ & Review and feedback & Before-after & $\begin{array}{c}\text { Significant reduction in } \\
\text { mechanical ventilation days } \\
(p=0.0053), \text { LOS }(p=0.0188) \text {, and } \\
\text { hospital mortality }(p=0.0367) . \text { NS } \\
\text { difference in medical ICU } \\
\text { mortality }(p=0.4970) .\end{array}$ \\
\hline $\begin{array}{l}\text { Lin et al., 2013, } \\
\text { Taiwan [75] }\end{array}$ & $\begin{array}{l}\text { 415-bed non-university } \\
\text { affiliated community } \\
\text { teaching hospital }\end{array}$ & $\begin{array}{l}\text { Education, prospective } \\
\text { review with intervention } \\
\text { and feedback }\end{array}$ & Before-after & $\begin{array}{l}\text { NS difference inLOS and } \\
\text { mortality. }\end{array}$ \\
\hline $\begin{array}{l}\text { Tsukamoto et al., } \\
\text { 2014, Japan [76] }\end{array}$ & $\begin{array}{l}\text { 600-bed university } \\
\text { teaching hospital }\end{array}$ & $\begin{array}{l}\text { Daily review and } \\
\text { feedback }\end{array}$ & Before-after & $\begin{array}{l}\text { 30-day mortality was lower in } \\
\text { post-intervention than } \\
\text { pre-intervention period ( } 14.3 \% \text { vs. } \\
\quad 22.9 \%, p=0.2)\end{array}$ \\
\hline $\begin{array}{l}\text { Pasquale et al., 2014, } \\
\text { USA [77] }\end{array}$ & $\begin{array}{l}\text { 577-bed community } \\
\text { teaching hospital }\end{array}$ & $\begin{array}{c}\text { De-escalation, dose } \\
\text { optimization, ID consult }\end{array}$ & $\begin{array}{l}\text { Retrospective } \\
\text { review of ASP } \\
\text { interventions in } \\
\text { patients with } \\
\text { ABSSSIs }\end{array}$ & $\begin{array}{c}\text { Mean LOS was shorter ( } 4.4 \text { days } \\
\text { vs. } 6.2 \text { days; } p<0.001 \text { ) compared } \\
\text { to historical data. } 30 \text {-day all-cause } \\
\text { readmission rate was lower }(6.5 \% \\
\text { vs. } 16.71 \%, p=0.05 \text { ) in } \\
\text { intervention group but } 30 \text {-day } \\
\text { ABSSSI readmission rate did not } \\
\text { differ between intervention and } \\
\text { historical groups ( } p=0.483 \text { ). }\end{array}$ \\
\hline
\end{tabular}


Table 4. Cont.

\begin{tabular}{|c|c|c|c|c|}
\hline Study & Setting & AMS Strategy & Design & Results \\
\hline $\begin{array}{l}\text { Lew et al., 2015, } \\
\text { Singapore [79] }\end{array}$ & $\begin{array}{c}\text { 1500-bed teaching } \\
\text { hospital }\end{array}$ & $\begin{array}{c}\text { De-escalation of } \\
\text { carbapenem therapy }\end{array}$ & $\begin{array}{c}\text { Retrospective } \\
\text { review of ASP } \\
\text { interventions }\end{array}$ & $\begin{array}{l}\text { NS difference in clinical success, } \\
\text { survival at discharge, } 30 \text { day } \\
\text { mortality, } 30 \text { day readmission and } \\
\text { LOS between de-escalated and } \\
\text { non-de-escalated groups. There } \\
\text { was difference in } \\
\text { antibiotic-associated diarrhea } \\
(4.4 \% \text { vs. } 12.5 \% ; p=0.015) \text { the } \\
\text { between the two groups. }\end{array}$ \\
\hline $\begin{array}{l}\text { Okumura, da Silva } \\
\text { \& Veroneze, 2015, } \\
\text { Brazil [80] }\end{array}$ & $\begin{array}{l}\text { 550-bed university } \\
\text { hospital }\end{array}$ & $\begin{array}{c}\text { Bundled ASP } \\
\text { comprisingdaily review } \\
\text { and feedback, } \\
\text { de-escalation, education, } \\
\text { follow up till resolution }\end{array}$ & $\begin{array}{l}\text { Retrospective } \\
\text { historical cohort }\end{array}$ & $\begin{array}{l}\text { 30-day mortality was lower with } \\
\text { bundled ASP ( } p<0.01 \text { ) than } \\
\text { conventional ASP (which } \\
\text { comprised passive chart review, } \\
\text { discussion with ID and telephone } \\
\text { call when intervention } \\
\text { was necessary). }\end{array}$ \\
\hline
\end{tabular}

\section{Discussion}

Our review identified a number of quality measures used in assessing ASP in primary studies. These include change in antimicrobial use, cost savings, resistance patterns of some difficult to treat organisms, rates of CDI, length of stay (LOS), readmission rate and mortality. These measures were classified into two main categories namely process and outcome measures [20,81]. Change in antimicrobial use (such as total quantity of antimicrobial or targeted antimicrobial class) measured usually in the WHO recommended defined daily dose (DDD)/100 or 1000 patient-days [81] is a process measure $[4,20]$. Other process measures recommended for use in assessing ASP include documentation of indication for antibiotic prescribed, documentation of stop/review date, 48-72 hours review after initiation of antibiotic therapy, level of adherence to hospital-specific guidelines, level of acceptance of AMS recommendations, time to appropriate therapy in patients with sepsis, and rate of de-escalation of initial therapy $[12,14,82]$. Outcome measures are categorized into microbiological, clinical and financial outcomes [82]. Microbiological outcomes include measures such as percentage of difficult to treat organisms e.g., MRSA, ESBL-producing Enterobacteriaceae, rate of isolation of resistant organisms, and rate of CDI [83]. Clinical outcome measures used in assessing impact of ASP include all-cause mortality, LOS and readmission rates; clinical improvement and rate of adverse antimicrobial reactions have also been recommended $[20,82,84]$.

Currently, there are no standard, universally accepted metrics for assessing ASP. For example, DDD whilst widely used in quantifying and reporting antimicrobial use continues to be debated because of its limitations [85]. The limitations of using DDD include its inability to provide information on the number of patients actually exposed to antibiotics; it cannot be used for children, and it underestimates the use for drugs that require reduced dosage due to renal impairment $[85,86]$. Morris et al. [18], in a structured panel to determine quality metrics for ASP, suggested days of therapy/1000 patient-days as a more appropriate measure for public reporting of ASP impact. Similarly, Aldeyab et al. [85] in a study that adjusted DDD to include age-adjusted comorbidity score (DDD/100 bed-days/age-adjusted comorbidity score) concluded that the modified unit provides "an innovative approach to measuring antibiotic use while taking into account the effect of patient case mix". Prescribed daily dose has also been suggested as an alternative or a complement to DDD [20]. Whether these metrics provide the appropriate standards for assessing ASP has not been determined. However, the majority of the studies that reported significant reductions in antimicrobial use employed DDD/1000 or 100 patient-days as the metric [24,33,34].

Assessing the impact of ASP on resistance using the identified metrics has inherent limitations. This is because several factors affect the development of resistance, which makes it difficult to establish a clear causal association between AMS interventions and decrease in resistance $[9,20,49]$. However, ASP especially those employing restriction on use of 'high-risk' antibiotic classes (second- 
and third-generation cephalosprins, fluoroquinolones) have been shown to reduce resistance and/or improve bacterial susceptibilities $[47,63,65]$. Although stewardship interventions have been shown to reduce resistance, their use as a primary measure for evaluating ASP has been cautioned [87]. Rate of CDI has been used as a measure for assessing ASP. Programs incorporating restriction or avoidance of the 'high-risk' antibiotic classes and clindamycin are notably associated with significant reduction in CDI rate $[42,44,51,52,54,58,63]$. Studies with marked reduction in CDI often also have strict infection control programs in place; which makes the association between ASP and the reduction in CDI rate difficult. However, infection control alone has been shown not to effectively control the outbreak of CDI. A significant reduction in rates followed stewardship interventions that involved restriction or avoidance of the 'high-risk' antibiotics [42,52,63].

The primary goal of ASP is to optimize patient outcomes. Six out of 13 studies included in this review reported non-significant difference in mortality $[69,71-73,75,79]$. Six studies reported shorter LOS between the pre- and post-intervention periods [68,70,72-74,77]. Notably, $\mathrm{Ng}$ et al. [70] reported significant difference in LOS between the periods before and after ASP implementation (7.46 and 6.97 respectively; $p<0.001)$. Interestingly, the same study reported statistically significant $(p<0.001)$ higher unplanned readmissions related to infections post-ASP.

Evaluation of ASP requires the use of patient-specific measures that demonstrate attainment of the primary goal. However, some limitations affect effective evaluation. These include difficulty in establishing a clear causal association between ASP interventions and measures such as mortality and LOS due to confounders that affect these measures $[9,20]$. Mortality related to antimicrobial-resistant organisms and infection-related hospital stay has been suggested as better patient measures for use in assessing impact [18,70]. Lack of personnel, funds, and health information technology personnel, and the inability to generate and analyze ASP-specific data have also been identified as limitations to effective ASP [9,88]. Inadequate study design also limits a clear association between ASP interventions and reported impact. Studies of interventions to improve hospital antimicrobial use are reported to be largely of poor design [11].

This review did not apply the strict quality criteria required for a systematic review of included studies, and risk of bias was not assessed. The purpose of this review was to provide an overview of the quality measures used in assessing ASP in primary studies, therefore all study designs were included. Studies assessing patient specific outcomes were of particular interest. Future work is planned to include evaluation and impact of ASP in pediatric patients.

\section{Conclusions}

Patient outcomes need to be a key component of ASP evaluation. The choice of metrics is influenced by data and resource availability. Controlling for confounders and unintended adverse consequences must be considered in the design of evaluation studies to adequately capture the impact of ASP. This review provides a starting pointfor compiling standard outcome metrics for assessing ASP.

Acknowledgments: Mary Richard Akpan is a doctoral student at the University of Hertfordshire, Hatfield. Her $\mathrm{PhD}$ is funded by University of Uyo, Nigeria and the Federal Republic of Nigeria. Raheelah Ahmad is partially funded by the National Institute for Health Research (NIHR) Health Protection Research Unit (HPRU-2012-10047) in Healthcare Associated Infections and Antimicrobial Resistance at Imperial College London in partnership with Public Health England (PHE) and the NIHR Imperial Patient Safety Translational Research Centre. The views expressed are those of the author(s) and not necessarily those of the NHS, the NIHR, the Department of Health or Public Health England. Naomi Fleming Advanced Pharmacist: Microbiology and Infectious Disease, Kettering General Hospital is acknowledged for her review and comments of the manuscript prior to submission of the revised manuscript.

Author Contributions: M.R.A. did the literature search and wrote the initial draft of the manuscript. R.A., N.A.S. and D.A.-O. discussed the draft and together produced the final version.

Conflicts of Interest: The authors declare no conflict of interest. 


\section{References}

1. World Health Organization. Antimicrobial Resistance: Global Report on Surveillance; World Health Organization: Geneva, Switzerland, 2014.

2. Department of Health. English Surveillance Program Antimicrobial Utilization and Resistance (ESPAUR) Report; Department of Health: London, UK, 2014.

3. European Centre for Disease Prevention and Control. Antimicrobial Resistance Surveillance in Europe; European Centre for Disease Prevention and Control: London, UK, 2013.

4. Dellit, T.; Owens, R.; McGowan, J.; Gerding, D.; Weinstein, R.; Burke, J.; Huskin, W.; Paterson, D.; Fishman, N.; Carpenter, C.; et al. Infectious Diseases Society of America and the Society for Healthcare Epidemiologyof America guidelines for developing an institutional program to enhance antimicrobial stewardship. Clin. Infect. Dis. 2007, 44, 159-177.

5. Tamma, P.D.; Holmes, A.; Ashley, E. Antimicrobial stewardship: Another focus for patient safety? Curr. Opin. Infect. Dis. 2014, 27, 348-355. [CrossRef] [PubMed]

6. Goossens, H.; French, M.; vander Stichele, R.; Elseviers, M.; ESAC Project Group. Outpatient antibiotic use in Europe and association with resistance: A cross-national database study. Lancet 2005, 365, 579-587. [CrossRef]

7. Aldeyab, M.; Harbarth, S.; Vernaz, N.; Kearney, M.; Scott, M.; Darwish Elhajji, F.; Aldiab, M.; McElnay, J. The impact of antibiotic use on the incidence and resistance pattern of extended-spectrum beta-lactamase-producing bacteria in primary and secondary healthcare settings. Br. J. Clin. Pharmacol. 2012, 74, 171-179. [CrossRef] [PubMed]

8. $\quad$ Livermore, D.; Hope, R.; Reynolds, R.; Blackburn, R.; Johnson, A.; Woodford, N. Declining cephalosporin and fluoroquinolone non-susceptibility among bloodstream Enterobacteriaceae from the UK: Links to prescribing change? J. Antimicrob. Chemother. 2013, 68, 2667-2674. [CrossRef] [PubMed]

9. Doron, S.; Davidson, L.E. Antimicrobial stewardship. Mayo Clin. Proc. 2011, 86, 1113-1123. [CrossRef] [PubMed]

10. Owens, R., Jr. Antimicrobial stewardship: Concepts and strategies in the 21st century. Diagn. Microbiol. Infect. Dis. 2008, 61, 110-128. [CrossRef] [PubMed]

11. Davey, P.; Brown, E.; Charani, E.; Fenelon, L.; Gould, I.; Holmes, A.; Ramsay, C.; Wiffen, P.; Wilcox, M. Interventions to improve antibiotic prescribing practices for hospital inpatients. Cochrane Database Syst. Rev. 2013, CD003543. [CrossRef]

12. Public Health England. Antimicrobial Stewardship: "Start Smart-Then Focus"; Public Health England: London, UK, 2015.

13. National Institute for Health and Care Excellence. Antimicrobial Stewardship:Systems and Processes for Effective Antimicrobial Medicine Use; National Institute for Health and Care Excellence: London, UK, 2015.

14. Australian Commission on Safety and Quality in Health Care. Antimicrobial Stewardship in Australian Hospitals; Duguid, M., Cruickshank, M., Eds.; Australian Commission on Safety and Quality in health Care: Sydney, Australia, 2011.

15. Patel, D.; Lawson, W.; Guglielmo, B.J. Antimicrobial stewardship programs: Interventions and associated outcomes. Exp. Rev. Anti-infect. Ther. 2008, 6, 209-222. [CrossRef] [PubMed]

16. Nathwani, D.; Gray, K.; Borland, H. Quality indicators for antibiotic control program. J. Hosp. Infect. 2002, 50, 165-169. [CrossRef] [PubMed]

17. Chen, A.; Khumra, S.; Eaton, V.; Kong, D. Snapshot of barriers to and indicators for antimicrobial stewardship in australian hospitals. J. Pharm. Pract. Res. 2011, 41, 37-41. [CrossRef]

18. Morris, A.; Brener, S.; Dresser, L.; Daneman, N.; Dellit, T.; Edina, A.; Chaim, B. Use of a structured panel process to define quality metrics for antimicrobial stewardship programs. Infect. Control Hosp. Epidemiol. 2012, 33, 500-506. [CrossRef] [PubMed]

19. Bumpass, J.; McDaneld, P.; DePestel, D. Outcomes and Metrics for Antimicrobial Stewardship: Survey of Physicians and Pharmacists. Clin. Infect. Dis. 2014, 59, S108-S111. [CrossRef] [PubMed]

20. Almirante, B.; Garnacho-Montero, J.; Pachón, J.; Pascual, Á.; Rodríguez-Baño, J. Scientific evidence and research in antimicrobial stewardship. Enferm. Infecc. Microbiol. Clin. 2013, 31, 56-61. [CrossRef]

21. Mercer, K.; Chintalapudi, S.; Visconti, E. Impact of Targeted Antibiotic Restriction on Usage and Cost in a Community Hospital. J. Pharm. Technol. 1999, 15, 79-84. 
22. Bassetti, M.; Biagio, A.; Rebesco, B.; Cenderello, G.; Amalfitano, M.; Bassetti, D. Impact of an antimicrobial formulary and restriction policy in the largest hospital in Italy. Int. J. Antimicrob. Agents 2000, 16, 295-299. [CrossRef]

23. Berild, D.; Ringertz, S.; Lelek, M.; Fosse, B. Antibiotic guidelines lead to reductions in the use and cost of antibiotics in a University Hospital. Scand. J. Infect. Dis. 2001, 33, 63-67. [PubMed]

24. Ansari, F.; Gray, K.; Nathwani, D.; Phillips, G.; Ogston, S.; Ramsay, C.; Davey, P. Outcomes of an intervention to improve hospital antibiotic prescribing: Interrupted time series with segmented regression analysis. J. Antimicrob. Chemother. 2003, 52, 842-848. [CrossRef] [PubMed]

25. Cook, P.; Catrou, P.; Christie, J.; Young, P.; Polk, R. Reduction in broad-spectrum antimicrobial use associated with no improvement in hospital antibiogram. J. Antimicrob. Chemother. 2004, 53, 853-859. [CrossRef] [PubMed]

26. Mcgregor, J.; Weekes, E.; Standiford, H.; Forrest, G.; Perencevich, E.; Furuno, J.; Harris, A. Impact of a Computerized Clinical Decision Support System on Reducing Inappropriate Antimicrobial Use: A Randomized Controlled Trial. J. Am. Med. Inf. Assoc. 2006, 13, 378-384. [CrossRef] [PubMed]

27. Siddiqui, S.; Hussein, K.; Manasia, R.; Samad, A.; Salahuddin, N.; Zafar, A.; Hoda, M. Impact of antibiotic restriction on broad spectrum antibiotic usage in the ICU of a developing country. J. Pak. Med. Assoc. 2007, 57, 484-487. [PubMed]

28. Cheng, V.; To, K.; Li, I.; Tang, B.; Chan, J.; Kwan, S.; Mak, R.; Tai, J.; Ching, P.; Ho, P.; Seto, W. Antimicrobial stewardship program directed at broad-spectrum intravenous antibiotics prescription in a tertiary hospital. Eur. J. Clin. Microbiol. Infect. Dis. 2009, 28, 1447-1456. [CrossRef] [PubMed]

29. Teo, J.; Kwa, A.; Loh, J.; Chlebicki, M.; Lee, W. The effect of a whole-system approach in an antimicrobial stewardship program at the Singapore General Hospital. Eur. J. Clin. Microbiol. Infect. Dis. 2012, 31, 947-955. [CrossRef] [PubMed]

30. Michael, K.; Mahdavi, M.; Krug, A.; Kuper, K. Implementation of an Antimicrobial Stewardship Program in a Community Hospital: Results of a Three-Year Analysis. Hosp. Pharm. 2012, 47, 608-616. [CrossRef]

31. Hagert, B.; Williams, C.; Wieser, C.; Rohrich, M.; Shien Lo, T.; Newman, W.; Koo, J. Implementation and Outcome Assessment of an Inpatient Antimicrobial Stewardship Program. Hosp. Pharm. 2012, 47, 939-945. [CrossRef]

32. Vettese, N.; Hendershot, J.; Irvine, M.; Wimer, S.; Chamberlain, D.; Massoud, N. Outcomes associated with a thrice-weekly antimicrobial stewardship program in a 253-bed community hospital. J. Clin. Pharm. Ther. 2013, 38, 401-404. [CrossRef] [PubMed]

33. Cisneros, J.; Neth, O.; Gil-Navarro, M.; Lepe, J.; Jiménez-Parrilla, F.; Cordero, E.; Rodríguez-Hernández, M.; Amaya-Villar, R.; Cano, J.; Gutiérrez-Pizarraya, A.; et al. Global impact of an educational antimicrobial stewardship program on prescribing practice in a tertiary hospital centre. Clin. Microbiol. Infect. 2014, 20, 82-88. [CrossRef] [PubMed]

34. Borde, J.; Kaier, K.; Steib-Bauert, M.; Vach, W.; Geibel-Zehender, A.; Busch, H.; Bertz, H.; Hug, M.; de With, K.; Kern, W. Feasibility and impact of an intensified antibiotic stewardship program targeting cephalosporin and fluoroquinolone use in a tertiary care university medical center. BMC Infect. Dis. 2014, 14, 201. [CrossRef] [PubMed]

35. Bartlett, J.; Siola, P. Implementation and first-year results of an antimicrobial stewardship program at a community hospital. Am. J. Health-Syst. Pharm. 2014, 71, 943-949. [CrossRef] [PubMed]

36. Hou, D.; Wang, Q.; Jiang, C.; Tian, C.; Li, H.; Ji, B. Evaluation of the Short-Term Effects of Antimicrobial Stewardship in the Intensive Care Unit at a Tertiary Hospital in China. PLoS ONE 2014, 9, e101447. [CrossRef] [PubMed]

37. Palmay, L.; Elligsen, M.; Walker, S. Hospital-wide Rollout of Antimicrobial Stewardship: A Stepped-Wedge Randomized Trial. Clin. Infect. Dis. 2014, 59, 867-874. [CrossRef] [PubMed]

38. Chandy, S.; Naik, G.; Charles, R.; Jeyaseelan, V.; Naumova, E.; Thomas, K.; Lundborg, C. The Impact of Policy Guidelines on Hospital Antibiotic Use over a Decade: A Segmented Time Series Analysis. PLoS ONE 2014, 9, e92206. [CrossRef] [PubMed]

39. Fukuda, T.; Watanabe, H.; Ido, S.; Shiragami, M. Contribution of antimicrobial stewardship programs to reduction of antimicrobial therapy costs in community hospital with 429 Beds-Before-after comparative two-year trial in Japan. J. Pharm. Policy Pract. 2014, 7, 10. [CrossRef] [PubMed] 
40. Cook, P.; Gooch, M. Long-term effects of an antimicrobial stewardship program at a tertiary-care teaching hospital. Int. J. Antimicrob. Agents 2015, 45, 262-267. [CrossRef] [PubMed]

41. Taggart, L.; Leung, E.; Muller, M.; Matukas, L.; Daneman, N. Differential outcome of an antimicrobial stewardship audit and feedback program in two intensive care units: A controlled interrupted time series study. BMC Infect. Dis. 2015, 15, 480. [CrossRef] [PubMed]

42. McNulty, C.; Logan, M.; Donald, I.; Ennis, D.; Taylor, D.; Baldwin, R.; Bannerjee, M.; Cartwright, K. Successful control of Clostridium difficile infection in an elderly care unit through use of a restrictive antibiotic policy. J. Antimicrob. Chemother. 1997, 40, 707-711. [CrossRef] [PubMed]

43. Carling, P.; Fung, T.; Killion, A.; Terrin, N.; Barza, M. Favourable impact of a multidisciplinary antibiotic management program conducted during 7 years. Infect. Control Hosp. Epidemiol. 2003, 24, 699-706. [CrossRef] [PubMed]

44. Khan, R.; Cheesbrough, J. Impact of changes in antibiotic policy on Clostridium difficile-associated diarrhoea (CDAD) over a five-year period in a district general hospital. J. Hosp. Infect. 2003, 54, 104-108. [CrossRef]

45. Saizy-Callaert, S.; Causse, R.; Furhman, C.; Le Paih, M.; Thébault, A.; Chouaïd, C. Impact of a multidisciplinary approach to the control of antibiotic prescription in a general hospital. J. Hosp. Infect. 2003, 53, 177-182. [CrossRef] [PubMed]

46. Bantar, C.; Sartori, B.; Vesco, E.; Heft, C.; Saúl, M.; Salamone, F.; Oliva, M. A hospital wide intervention program to optimize the quality of antibiotic use: Impact on prescribing practice, antibiotic consumption, cost savings, and bacterial resistance. Clin. Infect. Dis. 2003, 37, 180-186. [CrossRef] [PubMed]

47. Martin, C.; Ofotokun, I.; Rapp, R.; Empey, K.; Armitstead, J.; Pomeroy, C.; Hoven, A.; Evans, M. Results of an antimicrobial control program at a university hospital. Am. J. Health-Syst. Pharm. 2005, 62, 732-738. [PubMed]

48. Brahmi, N.; Blel, Y.; Kouraichi, N.; Lahdhiri, S.; Thabet, H.; Hedhili, A.; Amamou, M. Impact of ceftazidime restriction on gram-negative bacterial resistance in an intensive care unit. J. Infect. Chemother. 2006, 12, 190-194. [CrossRef] [PubMed]

49. Ntagiopoulos, P.G.; Paramythiotou, E.; Antoniadou, A.; Giamarellou, H.; Karabinis, A. Impact of an antibiotic restriction policy on the antibiotic resistance patterns of Gram-negative microorganisms in an Intensive Care Unit in Greece. Int. J. Antimicrob. Agents 2007, 30, 360-365. [CrossRef] [PubMed]

50. Mach, R.; Vlcek, J.; Prusova, M.; Batka, P.; Rysavy, V.; Kubena, A. Impact of a multidisciplinary approach on antibiotic consumption, cost and microbial resistance in a Czech hospital. Pharm. World Sci. 2007, 29, 565-572. [CrossRef] [PubMed]

51. Fowler, S.; Webber, A.; Cooper, B.; Phimister, A.; Price, K.; Carter, Y.; Kibbler, C.; Simpson, A.; Stone, S. Successful use of feedback to improve antibiotic prescribing and reduce Clostridium difficile infection: A controlled interrupted time series. J. Antimicrob. Chemother. 2007, 59, 990-995. [CrossRef] [PubMed]

52. Valiquette, L.; Cossette, B.; Garant, M.; Diab, H.; Pépin, J. Impact of a reduction in the use of high-risk antibiotics on the course of an epidemic of Clostridium difficile-associated disease caused by the hypervirulent NAP1/027 strain. Clin. Infect. Dis. 2007, 45, S112-S121. [CrossRef] [PubMed]

53. Ozorowski, T.; Kawalec, M.; Zaleska, M.; Konopka, L.; Hryniewicz, W. The effect of an antibiotic policy on the control of vancomycin-resistant enterococci outbreak and on the resistance patterns of bacteria isolated from the blood of patients in a hematology unit. Polskie Archiwum Medycyny Wewnetrznej 2009, 119, 712-718. [PubMed]

54. Talpaert, M.; Rao, G.; Cooper, B.; Wade, P. Impact of guidelines and enhanced antibiotic stewardship on reducing broad-spectrum antibiotic usage and its effect on incidence of Clostridium difficile infection. J. Antimicrob. Chemother. 2011, 66, 2168-2174. [CrossRef] [PubMed]

55. Altunsoy, A.; Cenk, A.; Alpay, A.; Önder, E.; İsmail, B. The impact of a nationwide antibiotic restriction program on antibiotic usage and resistance against nosocomial pathogens in Turkey. Int. J. Med. Sci. 2011, 8, 339-344. [CrossRef] [PubMed]

56. Cook, P.; Shemra, R.; Michael, G.; Jordan, M.; Fang, X.; Hudson, S. Sustained reduction in antimicrobial use and decrease in methicillin-resistant Staphylococcus aureus and Clostridium difficile infections following implementation of an electronic medical record at a tertiary-care teaching hospital. J. Antimicrob. Chemother. 2011, 66, 205-209. [CrossRef] [PubMed] 
57. Niwa, T.; Shinoda, Y.; Suzuki, A.; Ohmori, T.; Yasuda, M.; Ohta, H.; Fukao, A.; Kitaichi, K.; Matsuura, K.; Sugiyama, T.; et al. Outcome measurement of extensive implementation of antimicrobial stewardship in patients receiving intravenous antibiotics in a Japanese university hospital. Int. J. Clin. Pract. 2012, 66, 999-1008. [CrossRef] [PubMed]

58. Aldeyab, M.; Kearney, M.; Scott, M.; Aldiab, M.; Alahmadi, Y.; Elhajji, F.D.; Magee, F.; McElnay, J. An evaluation of the impact of antibiotic stewardship on reducing the use of high-risk antibiotics and its effect on the incidence of Clostridium difficile infection in hospital settings. J. Antimicrob. Chemother. 2012, 6, 12. [CrossRef] [PubMed]

59. Jaggi, N.; Sissodia, P.; Sharma, L. Impact of antimicrobial stewardship programme on carbapenem resistance in gram negative isolates in an Indian tertiary care hospital. Am. J. Infect. Dis. 2012, 8, 106-111.

60. Sarraf-Yazdi, S.; Sharpe, M.; Bennett, K.; Dotson, T.; Anderson, D.; Vaslef, S. A 9-Year retrospective review of antibiotic cycling in a surgical intensive care unit. J. Surg. Res. 2012, 176, E73-E78. [CrossRef] [PubMed]

61. Nowak, M.; Nelson, R.; Breidenbach, J.; Thompson, P.; Carson, P. Clinical and economic outcomes of a prospective antimicrobial stewardship program. Am. J. Health-Syst. Pharm. 2012, 69, 1500-1508. [CrossRef] [PubMed]

62. Malani, A.; Richards, P.; Kapila, S.; Otto, M.; Czerwinski, J.; Singal, B. Clinical and economic outcomes from a community hospital's antimicrobial stewardship program. Am. J. Infect. Control 2013, 41, 145-148. [CrossRef] [PubMed]

63. Dancer, S.; Kirkpatrick, P.; Corcoran, D.; Christison, F.; Farmer, D.; Robertson, C. Approaching zero: temporal effects of a restrictive antibiotic policy on hospital-acquired Clostridium difficile, methicillin-resistant Staphylococcus aureus and extended-Spectrum beta-lactamase producing coliforms in a district general hospital. Int. J. Antimicrob. Agents 2013, 41, 137-142. [CrossRef] [PubMed]

64. Wenisch, J.; Equiluz-Bruck, S.; Fudel, M.; Reiter, I.; Schmid, A.; Singer, E.; Chott, A. Decreasing Clostridium difficile Infections by an Antimicrobial Stewardship Program That Reduces Moxifloxacin Use. Antimicrob. Agents Chemother. 2014, 58, 5079-5083. [CrossRef] [PubMed]

65. Knudsen, J.; Andersen, S. A multidisciplinary intervention to reduce infections of ESBL- And AmpC-producing, Gram-negative bacteria at a university hospital. PLoS ONE 2014, 9, e86457. [CrossRef] [PubMed]

66. Sarma, J.; Marshall, B.; Cleeve, V.; Tate, D.; Oswald, T.; Woolfrey, S. Effects of fluoroquinolone restriction (from 2007 to 2012) on Clostridium difficile infections: interrupted time-series analysis. J. Hosp. Infect. 2015, 91, 74-80. [CrossRef] [PubMed]

67. Bartlett, J. A call to arms: The imperative for antimicrobial stewardship. Clin. Infect. Dis. 2011, 53, S4-S7. [CrossRef] [PubMed]

68. Gums, J.; Yancey, R.; Hamilton, C.; Kubilis, P. A randomized, prospective study measuring outcomes after antibiotic therapy intervention by a multidisciplinary consult team. Pharmacotherapy 1999, 19, 1369-1377. [CrossRef] [PubMed]

69. Chang, M.; Wu, T.; Wang, C.; Jang, T.; Huang, C. The impact of an intensive antimicrobial control program in a Taiwanese medical center. Pharm. World Sci. 2006, 28, 257-264. [CrossRef] [PubMed]

70. Ng, C.; Wu, C.; Chan, W.; Leung, Y.; Li, C.; Tsang, D.; Leung, G. Clinical and economic impact of an antibiotics stewardship programme in a regional hospital in Hong Kong. Qual. Safety Health Care 2008, 17, 387-392. [CrossRef] [PubMed]

71. Chan, Y.; Lin, T.; Huang, C.; Deng, S.; Wu, T.; Leu, H.; Chiu, C. Implementation and outcomes of a hospital-wide computerised antimicrobial stewardship program in a large medical centre in Taiwan. Int. J. Antimicrob. Agents 2011, 38, 486-492. [CrossRef] [PubMed]

72. Liew, Y.; Lee, W.; Loh, J.; Cai, Y.; Tang, S.; Lim, C.; Teo, J.; Ong, R.; Kwa, A.; Chlebicki, M. Impact of an antimicrobial stewardship program on patient safety in Singapore General Hospital. Int. J. Antimicrob. Agents 2012, 40, 55-60. [CrossRef] [PubMed]

73. DiazGranados, C. Prospective audit for antimicrobial stewardship in intensive care: Impact on resistance and clinical outcomes. Am. J. Infect. Control 2012, 40, 526-529. [CrossRef] [PubMed]

74. Rimawi, R.; Mazer, M.; Siraj, D.; Gooch, M.; Cook, P. Impact of Regular Collaboration between Infectious Diseases and Critical Care Practitioners on Antimicrobial Utilization and Patient Outcome. Crit. Care Med. 2013, 41, 2099-2107. [CrossRef] [PubMed] 
75. Lin, Y.; Lin, I.; Yen, F.; Lin, P.; Shiu, Y.; Hu, H.; Yang, Y. Impact of an antimicrobial stewardship program with multidisciplinary cooperation in a community public teaching hospital in Taiwan. Am. J. Infect. Control 2013, 41, 1069-1072. [CrossRef] [PubMed]

76. Tsukamoto, H.; Higashi, T.; Nakamura, T. Clinical effect of a multidisciplinary team approach to the initial treatment of patients with hospital-acquired bloodstream infections at a Japanese university hospital. Am. J. Infect. Control 2014, 42, 970-975. [CrossRef] [PubMed]

77. Pasquale, T.; Trienski, T.; Olexia, D.; Myers, J.; Tan, M.; Leung, A.; Poblete, J.; File, T., Jr. Impact of an antimicrobial stewardship program on patients with acute bacterial skin and skin structure infections. Am. J. Health-Syst. Pharm. 2014, 71, 1136-1139. [CrossRef] [PubMed]

78. Rosa, R.; Goldani, L.; dos Santos, R. Association between adherence to an antimicrobial stewardship program and mortality among hospitalised cancer patients with febrile neutropaenia: A prospective cohort study. BMC Infect. Dis. 2014, 14, 286. [CrossRef] [PubMed]

79. Lew, K.; Ng, T.; Tan, M.; Tan, S.; Lew, E.; Ling, L.; Ang, B.; Lye, D.; Teng, C. Safety and Clinical outcomes of carbapenem de-escalation as part of an antimicrobial stewardship program in an ESBL-endemic setting. J. Antimicrob. Chemother. 2015, 70, 1219-1225. [PubMed]

80. Okumura, L.; da Silva, M.; Veroneze, I. Effects of a bundled Antimicrobial Stewardship Program on mortality: A cohort study. Braz. J. Infect. Dis. 2015, 19, 246-252. [CrossRef] [PubMed]

81. WHO Collaborating Centre for Drug Statistics Methodology. Guidelines for ATC Classification and DDD Assignment; WHO Collaborating Centre for Drug Statistics Methodology: Oslo, Norway, 2012.

82. Septimus, E. Antimicrobial Stewardship-Qualitative and Quantitative Outcomes: The role of measurement. Curr. Infect. Dis. Rep. 2014, 16, 433. [CrossRef] [PubMed]

83. MacDougall, C.; Polk, R. Antimicrobial stewardship programs in health care systems. Clin. Microbiol. Rev. 2005, 18, 638-656. [CrossRef] [PubMed]

84. Fishman, N.; Society for Healthcare Epidemiology of America; Infectious Diseases Society of America and Pediatric Infectious Diseases Society. Policy Statement on Antimicrobial Stewardship by the Society for Healthcare Epidemiology of America (SHEA), the Infectious Diseases Society of America (IDSA), and the Pediatric Infectious Diseases Society (PIDS). Infect. Control Hosp. Epidemiol. 2012, 33, 322-327.

85. Aldeyab, M.; McElnay, C.; Scott, M.; Lattyak, W.; Darwish Elhajji, F.W.; Aldiab, M.; Magee, F.; Conlon, G.; Kearney, M. A modified method for measuring antibiotic use in healthcare settings: Implications for antibiotic stewardship and benchmarking. J. Antimicrob. Chemother. 2014, 69, 1132-1141. [CrossRef] [PubMed]

86. Polk, R.; Fox, C.; Mahoney, A.; Letcavage, J.; MacDougall, C. Measurement of Adult Antibacterial Drug Use in 130 US Hospitals: Comparison of Defined Daily Dose and Days of Therapy. Clin. Infect. Dis. 2007, 44, 664-670. [CrossRef] [PubMed]

87. Dodds Ashley, E.S.; Kaye, K.; DePestel, D.; Hermsen, E. Antimicrobial Stewardship: Philosophy versus Practice. Clin. Infect. Dis. 2014, 59, S112-S121. [CrossRef] [PubMed]

88. Pakyz, A.; Moczygemba, L.; vander Wielen, L.; Edmond, M.; Stevens, M.; Kuzel, A. Facilitators and barriers to implementing antimicrobial strategies: Results from a qualitative study. Am. J. Infect. Control 2014, 42, S257-S263. [CrossRef] [PubMed]

(C) 2016 by the authors; licensee MDPI, Basel, Switzerland. This article is an open access article distributed under the terms and conditions of the Creative Commons by Attribution (CC-BY) license (http://creativecommons.org/licenses/by/4.0/). 